\section{Students: Politics and Revolution}

\section{Philip G. Altbach}

Philip G. Altbach is Monan professor of higher education and director of the Center for International Higher Education at Boston College. Email: <altbach@bc.edu>.

$\mathrm{I}_{\mathrm{t}}^{\mathrm{n}}$ n July, university students in Iran came close to overthrowing the regime. They failed when conservatives within the government mobilized counter demonstrators and mounted their own street demonstrations. It is worth recalling that the downfall of the Shah two decades ago was precipitated by students from Tehran University. Less than a year ago, Indonesian students took to the streets and, after protracted demonstrations that resulted in major riots and deaths, forced the resignation of President Suharto and paved the way for recently concluded elections. These are but two examples of the power student movements have to influence politics and cause social unrest.

Students have played a pivotal role in the political and cultural history of many countries. They were central players in the independence movements that brought freedom to many developing countries. Campus social and political movements have been harbingers of change in many societies, from the pro-Nazi student fraternities in pre-Hitler Germany to the U.S. civil rights and antiwar movements in the 1960s. Student political movements might be compared to the proverbial canary in the coal mine-they may be a sign of a social explosion to come or of a building political crisis.

Yet not all student movements signal impending social crisis, and they are by no means always successful. If a regime is stable and has a modicum of legitimacy, it can usually survive. The government can sometimes use overwhelming repression to put down student revolts. This can be dangerous, since it can easily backfire. This occurred on the streets of Jakarta, when troops killed students at one of Indonesia's most prestigious universities, inflaming campus opinion and causing the mass media to turn against the government. In contrast, the Chinese authorities were able to use massive force to end the demonstrations at Tienanmin Square in 1989 by moving decisively and keeping control of the mass media. Further, the Chinese regime had better control over the security apparatus and greater legitimacy than President Suharto.

Student movements can topple governments only when the political system is already weakened and the regime has lost much of its legitimacy. Students have never caused the government of an industrialized country to fall. This is because the political systems are relatively stable and there are many competing political interests, organizations, and movements - from labor unions to political parties and the media. Only in the volatile 1960s did students cause significant unrest in Western countries. In France, President DeGaulle was forced to flee to a French military base in Germany and the survival of the government seemed precarious. In America, the anti-Vietnam War movement, led by students, forced President Lyndon Johnson not to run for re-election although it did not threaten the political system. In West Germany, radical students were a potent political force. The reasons for the power of students at this time were similar in each country-society was polarized and the established political parties were not functioning effectively. In the United States, Pres. Johnson's pledge to scale back in Vietnam was not honored and the war escalated; in France, DeGaulle had weakened parliament; and in Germany, the "grand coalition" of the two major parties left the country without an effective opposition and the students stepped in with an "extraparliamentary opposition" that expressed the views of a growing sector of German opinion.

\section{Students have played a pivotal role in the political and cultural history of many countries.}

Many developing countries have poorly institutionalized political systems and a weak public sphere. Their "civil society" - the web of voluntary organizations, the press and publishers, unions, political parties, and the like-is inadequate. There are many reasons for this. In some cases, the legacy of colonialism stunted the growth of institutions. The Congo, for example, had only a handful of university graduates at the time of independence. Poverty and illiteracy also hampered the establishment of civic institutions and stable governments. University students are among the few groups in society that possess the knowledge and the freedom to undertake political activism. And in many developing countries, a tradition of student political involvement dates back to the struggles against colonialism. In contrast, student politics is considered an illegitimate activity in the West-students are expected to attend university to study and not to engage in revolutionary activity. Not only do Western students have to contend with a rich mixture of competing organizations and movements, but their activism is not respected by most of the public. In developing countries, students are often seen as the "conscience of the nation."

The recent cases of Iran and Indonesia are illustrative. Iran's clerical establishment seems to have survived the current outbreak of student-led demonstrations. In both countries, political opposition has for many years been stifled, 
with a strictly controlled media. Academic freedom in the universities was restricted. There were few outlets for people to express their opposition to those in power, and in any case political expression courted arrest. Yet, both Iran and Indonesia have active middle classes and fairly high literacy rates, the basis for a civil society.

Students in these countries, and in many other Third World nations, were the only group in society able to express dissenting views. Students in developing countries, after all, come from relatively affluent and urbanized families. They are relatively easy to organize since they are on campus. The academic atmosphere, even in repressive societies such as Iran and Indonesia, is more liberal than in the surrounding society. Perhaps most important, higher education encourages inquiry and the questioning of established practices and institutions. It is not at all surprising that critical opinion will be expressed first among students.

In both countries, unrest spread quickly from the major universities in the capital and attracted the support of significant parts of the urban population. In Indonesia, the rot in the regime was sufficiently deep and social discontent, stimulated by the expanding economic crisis, strong enough to make repression impossible. Suharto was eventually forced to seek a peaceful solution to the crisis and to resign. The students did not achieve their intended goalthe ouster of the entire regime, since Suharto's successor, Habibie, was part of the old regime, and elections did not take place for a year.

In Iran, the conservative leadership was able to bring its own supporters out onto the streets and to dominate the mass media. The regime, through moderate levels of repression and the mobilization of its own supporters, proved that it retained a wellspring of support in society. In both countries, events are still evolving, and students may again play a central role.

Students precipitated the crisis, yet were unable to control events. This too is a common characteristic of student activism. Students have neither the power nor the organizational sophistication to maintain their movement and impose their will on society. Once the crisis takes place, other forces emerge. Often, the military seizes power, or political coalitions are able to cobble together a regime. In Indonesia, the political parties are slowly moving toward creating a government following recent elections. In Iran, the conservative Islamic clerics have, at least for the present, kept power.

University students are a powerful force in many countries. They both shape and express public opinion and cultural attitudes. Often at the forefront of political and social change, they deserve to be understood-and respected.

Note: This article also appears in Change (SeptemberOctober, 1999).

\section{The Academy and the Public Realm}

\section{Zelda F. Gamson}

Zelda F. Gamson is senior associate, New England Resource Center for Higher Education. Address: New England Resource Center for Higher Education, University of Massachusetts, Boston MA 02105, USA. Email: <gamson@umbsky.cc.umb.edu>.

W That is meant by the "public realm?" There is quite a literature on this question. At its base, the public realm is a place and a process whereby citizens become engaged in public life. This engagement can be passive, as in voting for officials who are expected to represent the interests of the citizenry, or it can be active, as in participating in decisions that affect citizens' lives. The forms of expression in the public realm can include formal decision making, rational arguments presented by knowledgeable people, debate, discussion, and storytelling. Participants can be experts and ordinary citizens, activists and nonactivists. Issues up for discussion can include questions of general public concern or they can be of concern to certain groups or a certain locale.

Why is the public realm so important? Most of us recognize that political life in the United States (and many other nations) is in some trouble. Some social scientists see a decline in participation in civic organizations, marked by a decline in membership in voluntary groups. Others have pointed out that while membership in the traditional organizations may have indeed declined a new kind of citizenship is on the rise. Sociologists Carmen Sirianni and Lewis Friedland point to growing participation in grassroots problem-solving activities, "civic innovations," such as the healthy communities movement and local efforts to counter youth violence. There are counterparts to these innovations in other countries among nongovernmental organizations, many of them founded and headed by women.

Modern Tocquevillians do see a breakdown in civic life that cannot be captured by statistics about volunteer activities and local participation. Some argue that the overemphasis on individual choice and personal development undermines deeper social commitments. The fragmentation of society into groups based on class, religion, gender, sexual orientation, race, and ethnicity-argue commentators like Jean Bethke Elshtain and Todd Gitlin-weakens efforts to forge shared commitments among people who have more in common than they think.

I am convinced that the reason for the decline of civic life does not lie with ordinary citizens, who have shown tremendous creativity and good sense in the way they have engaged in public life. Rather, the problem lies with elites and their institutions. Wealthy people across the globe have gone their own way, reaping the benefits of their position 